\title{
NGF Modulates Sympathetic Innervation of Lymphoid Tissues
}

\author{
Sonia L. Carlson, ${ }^{1}$ Kathryn M. Albers, ${ }^{2}$ Daniel J. Beiting, ${ }^{1}$ Mark Parish, ${ }^{1}$ James M. Conner, ${ }^{3}$ and Brian M. \\ Davis' \\ 'Department of Anatomy and Neurobiology and ${ }^{2}$ Department of Pathology, University of Kentucky College of \\ Medicine, Lexington, Kentucky 40536-0084 and ${ }^{3}$ Department of Biology, University of California at San Diego, La \\ Jolla, California 92093-0601
}

Immune tissues are known to be innervated by the sympathetic nervous system, but little is known of what directs the innervation to specific tissue compartments. This report examines the sympathetic innervation of immune tissues in transgenic mice that overexpress nerve growth factor (NGF) in skin and other epithelial structures. NGF transgenic mice exhibited dramatic hyperinnervation in the splenic marginal zone, and the medulla and capsule of peripheral lymph nodes. In contrast, the transgenic mesenteric lymph nodes showed no hyperinnervation. This difference correlated with the location of these nodes; peripheral lymph nodes drain skin where the transgene was expressed while mesenteric lymph nodes drain non-transgene-expressing structures. In addition, the level of innervation correlated with the level of NGF peptide content as assayed by ELISA (3- and 13-fold increase in transgenic spleen and axillary lymph nodes, respectively; no increase in mesenteric nodes) and immunocytochemistry. RT-PCR showed that the NGF transgene was not being expressed in the immune tissues, suggesting that immune tissues can concentrate transgene-produced NGF. It was also demonstrated that the change in innervation had functional consequences. The mitogen response to concanavalln $A$ (ConA) by spleen cells was decreased in the transgenics suggesting that elevated catecholamines or NGF can modulate the proliferative response of these cells. These mice demonstrate that NGF can modulate the sympathetic innervation and function of the immune system.

[Key words: NGF, tyrosine hydroxylase, spleen, lymph node, mitogen, immune]

Numerous studies have shown communication between the nervous system and the immune system. In particular, the sympathetic nervous system has been well documented to innervate lymphoid tissues (Felten and Felten, 1991) and to modulate immune responses (Madden and Livnat, 1991; Roszman and Carlson, 1991). In general, sympathetic fibers in immune tissues are found surrounding blood vessels and in T-cell zones within lymphoid tissues such as spleen, lymph nodes, gut-associated lym-

\footnotetext{
Received Apr. 4, 1995; revised May 18, 1995; accepted May 22, 1995.

We thank Karen Abell and Frankie Davis for excellent technical assistance This work was supported by MH-48644 to S.L.C. and NS-31826 to B.M.D. and K.M.A

Correspondence should be addressed Sonia L. Carlson, Ph.D., Department of Anatomy and Neurobiology, University of Kentucky Medical Center, Lexington, KY 40536-0084.

Copyright (C) 1995 Society for Neuroscience $0270-6474 / 95 / 155892-08 \$ 05.00 / 0$
}

phoid tissue (GALT), etc. (Felten et al., 1987). Examination of splenic innervation at the electron microscopic level shows nerve terminals directly adjacent to lymphocytes in the white pulp and thus these fibers do not innervate solely the smooth muscle of arteries (Felten and Olschowka, 1987). Lymphocytes also express $\beta$-adrenergic receptors (Pochet et al., 1979; Krawietz et al., 1982; Carlson et al., 1994), and can respond functionally to catecholamines released into their microenvironment. Catecholamine stimulation of lymphocytes has been shown to modulate various aspects of immune function including lymphocyte proliferation, antibody production, natural killer cell activity and lymphocyte homing (reviewed in Madden and Livnat, 1991).

It is not known what "directs" the sympathetic axons to innervate specific compartments of lymphoid tissues. One potential guidance molecule is NGF, a neurotrophic protein known to be required for sympathetic neuron survival and differentiation (Levi-Montalcini and Angeletti, 1968; Harper and Thoenen, 1980), and to support sympathetic innervation in other tissues. Previous studies have shown that the level of sympathetic innervation of many tissues is correlated with the level of NGF peptide (Korsching and Thoenen, 1983; Shelton and Reichardt, 1984). To examine the role of NGF in regulation of the innervation pattern of lymphoid tissue, we have studied transgenic mice that overexpress NGF. These transgenic mice express a transgene in which the NGF cDNA was linked to an epidermal keratin (K14) gene promoter and enhancer sequences. They express high levels of NGF in the skin and other stratified epithelium beginning at approximately embryonic day 14, resulting in hyperinnervation of this tissue by sensory and sympathetic axons (Albers et al., 1994). Although the NGF transgene is not expressed in the lymphoid tissues, the spleen and peripheral lymph nodes of the K14-NGF transgenics had a profound sympathetic hyperinnervation in specific tissue compartments, including the marginal zone of the spleen and the medulla and capsule of peripheral lymph nodes. In contrast, the mesenteric lymph nodes of the gut were not hyperinnervated. The mitogen response of spleen cells to ConA was significantly decreased in the transgenics. Thus, these mice provide a means to determine the role of neurotrophins in the development of innervation of lymphoid tissues and the functional consequence of hyperinnervation on immune function.

\section{Materials and Methods}

Transgenic mice. The K14-NGF transgenic mice used in this study have previously been described (Albers et al., 1994). In brief, a $797 \mathrm{bp}$ fragment encoding the NGF short transcript (Edwards et al., 1989) was ligated into a K14-hGH cassette vector (Cheng et al., 1992). This vector 
contains the human keratin $\mathrm{K} 14$ gene promoter and enhancer that directs high levels of transgene expression to basal keratinocytes of the epidermis. Mice expressing the K14-NGF transgene were isolated as described previously (Albers et al., 1994) and screened for the transgene using Southern hybridization analysis and slot blot analysis using DNA extracted from tail. Relative levels of transgene expression were determined by Northern analysis based on the hybridization signal and two lines, A-47 and A-56, were chosen for analysis. Line A-47 (medium expresser) has a lower level of transgene mRNA expression and skin hyperinnervation than line A-56 (high expresser) (Albers et al., 1994).

Tyrosine hydroxylase immunocytochemistry. Mice were deeply anesthetized, perfused intracardially with buffered $4 \%$ paraformaldehyde, and tissues removed, weighed, embedded in gelatin (10\% in PBS) and postfixed overnight. Tissues were transferred to $30 \%$ sucrose in PBS and kept at $4{ }^{\circ} \mathrm{C}$ overnight. Sections were cut at $30 \mu \mathrm{m}$ on a freezing microtome and stored in a cryoprotectant solution (Watson et al., 1986). Sections to be stained were rinsed several times in KPBS (40 mm $\mathrm{K}_{2} \mathrm{HPO}_{4}, 10 \mathrm{mM} \mathrm{KH} \mathrm{PO}_{4}, 0.9 \% \mathrm{NaCl}, \mathrm{pH} 7.2$ ), incubated $30 \mathrm{~min}$ in $4 \%$ goat serum, and incubated overnight at $4{ }^{\circ} \mathrm{C}$ with primary antibody $(0.05 \mu \mathrm{g} / \mathrm{ml}$ rabbit anti-TH, Chemicon) in KPBS with $0.02 \%$ Triton $\mathrm{X}-100$. After six rinses, tissues were incubated with biotinylated secondary antibody (goat anti-rabbit, $5 \mu \mathrm{g} / \mathrm{ml}$, Kirkegaard and Perry, Gaithersburg, MD) for $60 \mathrm{~min}$ at room temperature. Sections were rinsed and endogenous peroxidase activity blocked by incubating for $20 \mathrm{~min}$ in $\mathrm{KPBS}$ containing $2.5 \% \mathrm{H}_{2} \mathrm{O}_{2}$ and $5 \%$ methanol. After rinsing, sections were incubated with avidin-biotin complex (ABC kit, Vector Labs) for $60 \mathrm{~min}$, rinsed one time in KPBS and two times in sodium acetate buffer $(0.1 \mathrm{M}, \mathrm{pH} 6)$. The immunoreactivity was visualized using nickel-enhanced 3,3'-diaminobenzidine (DAB, $0.4 \mathrm{mg} / \mathrm{ml}$ ) and $\mathrm{H}_{2} \mathrm{O}_{2}$ $(0.005 \%)$ in sodium acetate buffer. Tissue sections were mounted on slides, counterstained with methyl green, dehydrated through a graded series of alcohols and xylene, and coverslipped with Permount.

NGF immunocytochemistry. The pattern of NGF staining was determined using a rabbit-anti-NGF antibody (Conner et al., 1992). Animals were perfused with $2 \%$ paraformaldehyde with $0.2 \%$ parabenzoquinone in PBS. Tissues were embedded in $10 \%$ gelatin, postfixed $2 \mathrm{hr}$, and processed and cut as above for TH staining. All immunocytochemistry steps were carried out in $0.1 \mathrm{~mm}$ Tris buffered saline (TBS), pH 7.4. Tissue sections were pretreated with $0.25 \%$ Triton $X-100$ in TBS for $20 \mathrm{~min}$, and then blocked with $5 \%$ goat serum, $2 \%$ bovine serum albumin in TBS for $1 \mathrm{hr}$. Sections were incubated with the anti-NGF antibody $(2 \mu \mathrm{g} / \mathrm{ml})$ for $48 \mathrm{hr}$ at $4^{\circ} \mathrm{C}$. The secondary antibody (biotinylated goat anti-rabbit, $1.5 \mu \mathrm{g} / \mathrm{ml}$, Vector Laboratories, Burlingame, CA) was incubated for $3 \mathrm{hr}$, room temperature. The ABC step (Vector Laboratories) was incubated for $90 \mathrm{~min}$. The color reaction was developed using $0.4 \mathrm{mg} / \mathrm{ml} \mathrm{DAB}, 0.06 \%$ nickel chloride, $0.06 \% \mathrm{H}_{2} \mathrm{O}_{2}$ in TBS.

Reverse transcriptase-PCR. Total RNA was isolated from tissues using Trizol (BRL, Grand Island, NY), resuspended in sterile water, and DNased (Promega Biotechnology, Madison, WI). One $\mu \mathrm{g}$ of each sample was reverse transcribed using Superscript reverse transcriptase (BRL) following the manufacturer's protocol. Reverse transcribed samples were denatured at $99^{\circ} \mathrm{C}$ for $5 \mathrm{~min}$, put on ice $5 \mathrm{~min}$, and split into two. separate tubes. PCR amplification was carried out in a $100 \mu \mathrm{l}$ volume following addition of $1.5 \mathrm{U}$ of Taq polymerase (Promega) and a primer set $(20 \mu \mathrm{M}$ each) to either $\mathrm{N}(\mathrm{it}$ or actin sequences. Actin served as an internal standard for RNA quality and reaction efficiency. Reaction conditions for NGF amplification were: 1 min: $94^{\circ} \mathrm{C}, 1 \mathrm{~min}$ : $58^{\circ} \mathrm{C}, 1 \mathrm{~min}: 72^{\circ} \mathrm{C}$ for 25 cycles. Actin amplification was carried out in separate tubes for 20 cycles. Following amplification, reactions were extracted with $100 \mu \mathrm{l}$ of chloroform to remove the overlying mineral oil and $90 \mu \mathrm{l}$ of each reaction precipitated with ammonium acetate and ethanol. DNA pellets were resuspended in $10 \mathrm{~mm}$ Tris, $1 \mathrm{~mm}$ EDTA $\mathrm{pH} 8$ and run on an $8 \%$ polyacrylanide gel in TBE buffer that was stained with ethidium bromide. To detect endogenous and transgene NGF DNAs, internal primers to the NGF sequence were utilized (5'TCCAATCCTGTTGAGAGTGG 3'; 5'CAGGCTGTGTCTATCCGGAT $3^{\prime}$ ). Amplification produced a 144 bp fragment. Actin primers (5'TAAAACGCAGCTCAGTAACAGTCCG 3'; 5'TGGAATCCTGTGGCATCCATGAAAC $3^{\prime}$ ) produced a 348 bp fragment. To detect transgene expression, primers to sequences at the $3^{\prime}$ end of the NGF $\operatorname{cDN} \Lambda\left(5^{\prime}\right.$ GG $\left.\Lambda T \wedge G \wedge C \wedge C \wedge G C C T G T G T G 3^{\prime}\right)$ and at the $5^{\prime}$ end of the hGH noncoding region ( $5^{\prime}$ AAAAGCCAGGAGCAGGGACGT $3^{\prime}$ ) were used (see Albers et al., 1994). This region contained an intron sequence specific for the transgene and further verified that only mRNA and not DNA sequences were amplified.

NGF ELISA. The ELISA was carried out according to the protocol of Creeden and Tuttle (1988). Fresh frozen tissue samples were sonicated briefly in ice cold sample buffer $(0.1 \mathrm{M}$ PBS, $0.4 \mathrm{M} \mathrm{NaCl}, 0.1 \%$ Triton X-100, 2 mм EDTA, 0.5\% BSA pH 7.4; plus protease inhibitors added just prior to use from $100 \times$ stocks: $0.1 \mathrm{~mm}$ benzethonium chloride, $2 \mathrm{~mm}$ benzamidine, $0.1 \mathrm{~mm}$ PMSF, and $20 \mathrm{KIu} / \mathrm{ml}$ aprotinin). The samples were centrifuged $10 \mathrm{~min}$ at $40,000 \times g, 4^{\circ} \mathrm{C}$, and the supernatants transferred to new microfuge tubes. Tissue pellets were saved for protein measurement. The ELISA plate was coated with anti-NGF antibody $(0.25 \mu \mathrm{g} / \mathrm{ml}$ in binding buffer: $50 \mathrm{~mm}$ sodium carbonate $/ \mathrm{bi}-$ carbonate, pH 9.6; Boehringer Mannheim \#1008 218, Chicago, IL) for $2 \mathrm{hr}, 37^{\circ} \mathrm{C}$. The antibody was removed, and the wells blocked with 10 $\mathrm{mg} / \mathrm{ml} \mathrm{BSA}$ in binding buffer for $1 \mathrm{hr}, 37^{\circ} \mathrm{C}$, washed $4 \times$ with wash buffer, and the samples and NGF standards $(15.6-1000 \mathrm{pg} / \mathrm{ml})$ added in triplicate. The plate was sealed and incubated overnight at room temperature. The wells were washed $1 \times 1 \mathrm{~min}$, and $3 \times 20 \mathrm{~min}$ using a plate shaker. The secondary anti-NGF antibody conjugated to $\beta$-galactosidase $(10 \mathrm{mU} / \mathrm{ml}$, Boehringer Mannheim, \#10088 234) was added and incubated for $3 \mathrm{hr}$ at $37^{\circ} \mathrm{C}$. The plate was washed $3 \times 30 \mathrm{~min}$, fluorescein di- $\beta$-galactopyranoside (FDG $25 \mu \mathrm{M}$, Molecular Probes, Eugene, OR) was added as a substrate for $\beta$-galactosidase, and the plate sealed and incubated overnight at $37^{\circ} \mathrm{C}$. The fluorescence per well was measured using a CytoFluor 2300 fluorescence plate reader (Millipore, Bedford, MA; Ex $485 \mathrm{~nm}$; Em $530 \mathrm{~nm}$ ), and the results calculated from the standard curve.

Mitogen response. Spleens of control and transgenic mice were aseptically removed and dissociated into cell suspensions in wash medium [Hanks' Balanced Salt Solution (HBSS), $20 \mathrm{mM}$ HEPES, 0.5\% BSA]. Spleen cells were pelleted by centrifugation at $200 \times \mathrm{g}, 10 \mathrm{~min}$, and resuspended in lysis buffer $\left(0.15 \mathrm{M} \mathrm{NH}_{4} \mathrm{Cl}, 0.1 \mathrm{~mm}\right.$ EDTA, $1.0 \mathrm{~mm}$ $\mathrm{KHCO}_{3}, \mathrm{pH} \mathrm{7.4)}$ for $10 \mathrm{~min}, 4^{\circ} \mathrm{C}$, to eliminate red blood cells. Spleen cells were washed twice in wash buffer, resuspended in complete medium [Dulbecco's Modified Eagles Medium, $2 \mathrm{~mm}$ L-glutamine, $1 \times$ nonessential amino acids (GIBCO, Grand Island, NY), $50 \mu \mathrm{M} 2$-mercaptoethanol, $10 \mathrm{~mm}$ HEPES, $100 \mathrm{U} / \mathrm{ml}$ penicillin, $100 \mu \mathrm{g} / \mathrm{ml}$ streptomycin, 10\% alpha calf serum (HyClone, Salt Lake City, UT)] and adjusted to $2 \times 10^{6} / \mathrm{ml}$. Cells $(100 \mu \mathrm{l})$ were added to 96 well plates containing $100 \mu \mathrm{l}$ of $2 \times$ solutions of Con A (Sigma Chemical, St. Louis, MO) diluted in complete medium. The final concentrations of ConA were $0,1,2.5$, and $5 \mu \mathrm{g} / \mathrm{ml}$, with all groups plated in triplicate. The plates were incubated for $72 \mathrm{hr}$ at $37^{\circ} \mathrm{C}$ in a humidified $5 \% \mathrm{CO}_{2}$ incubator. During the last hour of incubation, $20 \mu \mathrm{l}$ of Alamar blue (Alamar, Sacramento, CA) was added, and the plates read using a CytoFluor 2300 fluorescence plate reader (Millipore, Bedford, MA; Ex: $530 \mathrm{~nm}$, Em: $590 \mathrm{~nm}$ ). Wells containing medium plus Alamar blue were used for background subtraction. The combined data of replicate experiments for the transgenic mice are expressed as percent of control values. A Student's $t$ test was used with each concentration of ConA to determine significant differences. Previous studies from our lab (unpublished observations) and others (Ahmed et al., 1994) have shown a good correlation between proliferation results using Alamar blue and ${ }^{3} \mathrm{H}$-thymidine incorporation.

\section{Results}

Spleen innervation is enhanced in K14-NGF transgenic mice. To investigate the effect of NGF overexpression on the sympathetic innervation paltern of various lymphoid tissues, tissue sections from control and K14-NGF transgenics were incubated with an antibody against tyrosine hydroxylase $(\mathrm{TH})$, the rate limiting enzyme in catecholamine biosynthesis. Antibody labeling of control spleen showed a dense innervation surrounding the central artery of the white pulp (Fig. 1A). In addition, nerve fibers extended away from the central artery into the white pulp parenchyma, consistent with the previously described pattern in rat and mouse (Felten et al., 1987). TH-positive fibers were not found in the red pulp, and only occasionally seen in the marginal zone of the white pulp. In contrast, splenic tissue from the high expresser (A-56 line) K14-NGF transgenic mice consistently had a dense innervation in the marginal zone, forming a sharp boundary around each area of white pulp (Fig. $1 B$ ). The plexus 

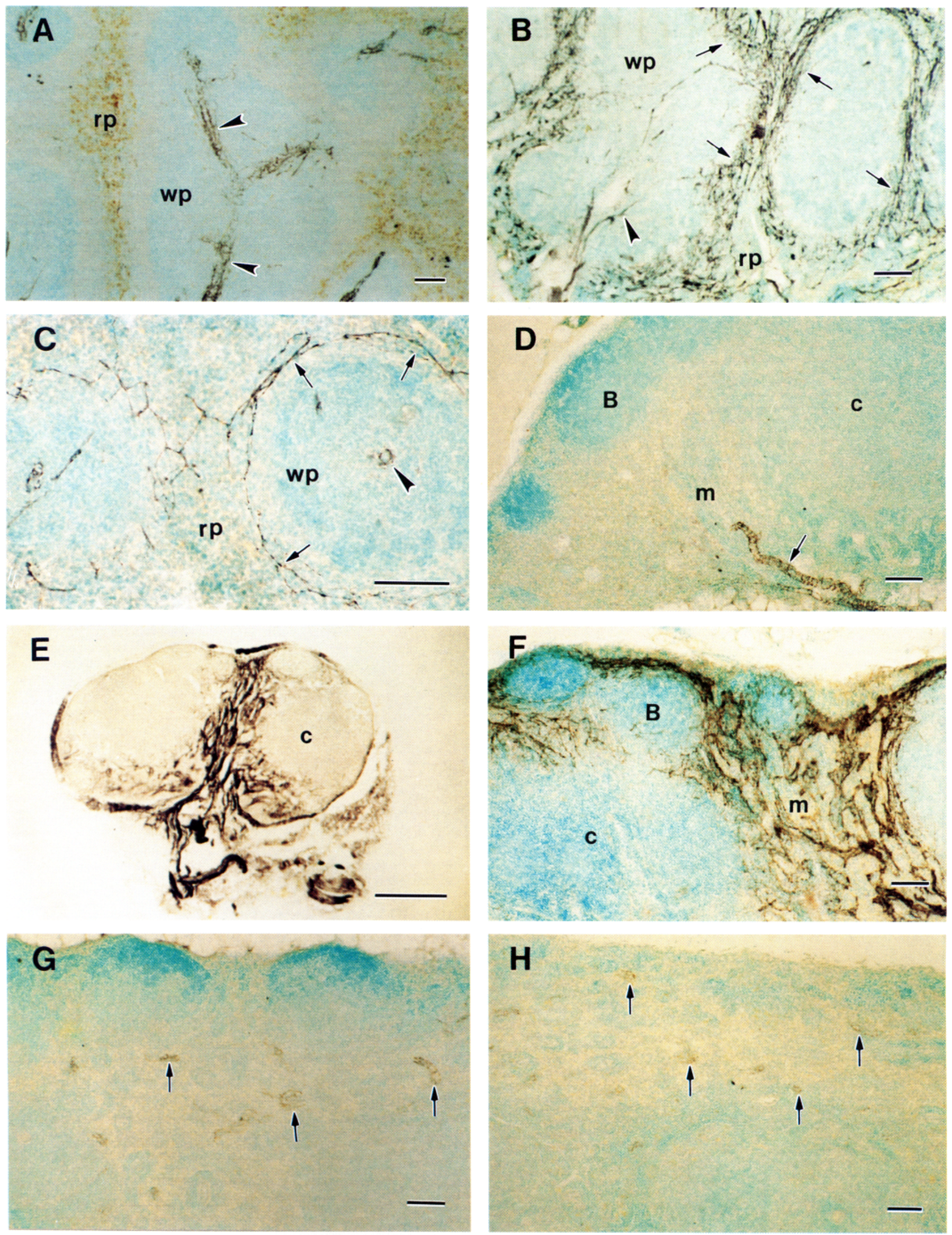

H 
in the marginal zone was composed of a dense network of finc fibers. Innervation of the central artery and white pulp parenchyma were present, but often appeared less dense than in controls. In many transgenics, numerous coarse fiber bundles were located in the red pulp. Large nerve fiber bundles could be seen entering the tissue.

Spleen tissue from medium expresser (A-47 line) NGF mice showed a pattern of innervation that was intermediate between the control and high expresser pattern (Fig. 1C). The central artery innervation was robust, but fibers also were found in the marginal zone. The marginal zone plexus consisted of a few fibers ringing the white pulp in contrast to the heavy plexus of fibers seen in the high expresser animals. Some TH-labeled fibers were seen in the red pulp, but at a much lower level than present in the high expresser animals.

Innervation of peripheral and mesenteric lymph nodes. Sympathetic innervation of peripheral lymph nodes (axillary, ccrvical, inguinal) in control animals was sparse, with most fibers around blood vessels in the medulla (Fig. $1 D$ ). In contrast, large TH-positive nerve fiber bundles were detected entering the hilus region of lymph nodes in the high expresser transgenic mice (Fig. $1 E$ ). Nerve fibers ramified from the hilus, extending to the adjacent capsular and subcapsular regions and into the medulla (Fig. $1 E, F$ ). The medullary region was extremely hyperinnervated, with sharp demarcations at the cortico-medullary junction as the TH-labeled fibers did not extend into the cortex. The THpositive fibers extended to the capsule adjacent to the medulla, but in most cases did not innervate the entire capsule. Although the cortex of the lymph node did not appear innervated, THpositive fibers circled around B-cell follicles at the periphery of the cortex, without sending fibers into the follicles. In general, the peripheral lymph nodes with the highest level of innervation were the cervical and axillary nodes. In some transgenic mice, the innervation of the inguinal lymph nodes appeared less robust. The popliteal lymph nodes were examined in one animal and were hyperinnervated as well (data not shown). In the medium expresser mice, the sympathetic innervation of the peripheral lymph nodes was enhanced and, though a fiber distribution similar to that in high expressers was present, the overall density of innervation was considerably less (data not shown).

Innervation of mesenteric lymph nodes in control mice was similar to that present in control peripheral nodes (Fig. 1G). Small plexuses of fibers surrounded blood vessels and extended into the medullary regions. Surprisingly, the innervation of the mesenteric lymph nodes of the high and medium K14-NGF expressing mice did not differ from the pattern and intensity seen in controls (Fig. $1 H$ ).

NGF peptide levels are elevated in lymphoid tissues of NGF transgenic mice. One possible explanation for the hyperinnervation of the lymphoid tissues in the transgenics is that they
Table 1. NGF peptide content is elevated in high-expresser transgenic spleen and axillary lymph node

$\begin{array}{lc}\text { Tissue } & \text { \% of nontransgenic } \\ \text { NGF content }\end{array}$

The data represent the mean \pm SEM of tissues from 9-13 transgenic mice and 5-10 controls. Average NGF content of control (nontransgenic) tissues (pg NGF/mg protein): spleen, $25.74 \pm 2.34$; axillary lymph node, $7.98 \pm 2.45$; mesenteric lymph node, $32.44 \pm 10.41$.

contained higher levels of NGF and thus supported greater levels of innervation. To determine if this was the case, the levels of NGF were measured in control and high-expresser transgenic spleens using a two-site ELISA and fluorescence detection. The NGF level in the transgenic spleens was threefold higher than measured in controls (Table 1). In axillary lymph nodes, the level of NGF in the high-expresser transgenics was more variable than controls, but the mean level was approximately 13fold higher than in controls. NGF levels in transgenic mesenteric lymph node were not different than control values. Thus, in contrast to transgenic axillary lymph nodes and spleen, transgenic mesenteric lymph nodes did not have elevated NGF.

Immunocytochemical staining for NGF. To localize NGF within lymphoid tissues, immunocytochemical staining for NGF was carried out. The pattern of NGF staining was similar to that seen with TH immunocytochemistry. In control spleen NGFpositive fibers surrounded the central artery (Fig. 2A). In NGF transgenic spleens, fibers were distributed in the marginal zone as well as in the white pulp surrounding the central artery (Fig. $2 B$ ). In both controls and transgenics the staining was relatively light. In control axillary lymph nodes, no specific staining for $\mathrm{NGF}$ was apparent (Fig. $2 \mathrm{C}$ ). In contrast, anti-NGF staining was very intense in the medulla and capsule of the NGF transgenic axillary lymph nodes (Fig. $2 D$ ). No specific staining was detected in either the control or transgenic mesenteric lymph nodes (Fig. 2E,F).

Measures of endogenous and transgene NGF expression using RT-PCR. One possible explanation for the elevated NGF peptide levels in the transgenic tissues is that the K14-NGF transgene was aberrantly expressed in these tissues. Alternatively, the endogenous expression of NGF could have been elevated. To examine the level of NGF mRNA expression in lymphoid tissues of control and transgenic mice, we used reverse transcriptase-polymerase chain reaction (RT-PCR) analysis. Analysis of total NGF mRN $\Lambda$ expression, that is, endogenous and transgene derived, was done on axillary and mesenteric lymph

$\leftarrow$

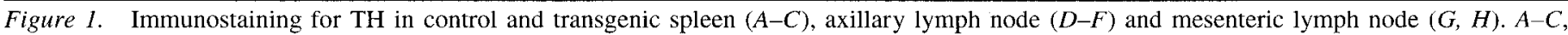

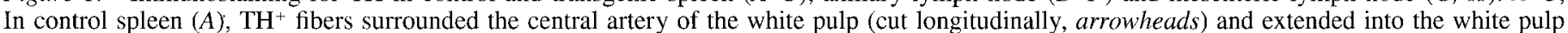

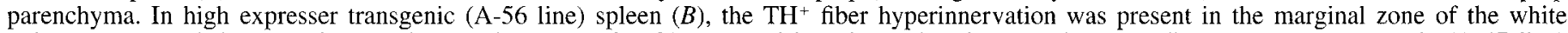

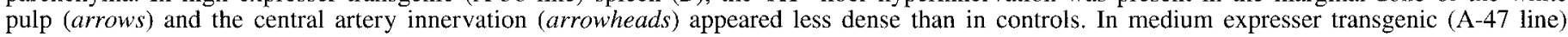

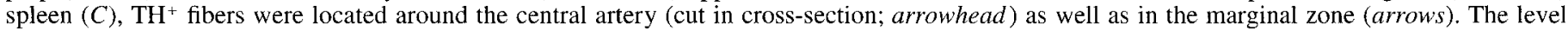

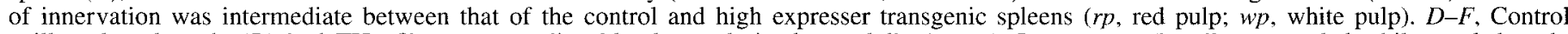

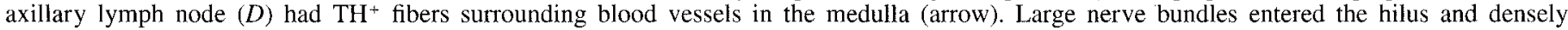

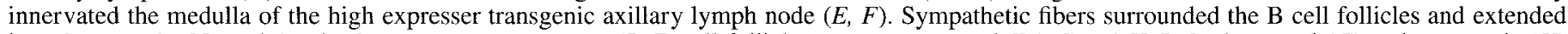

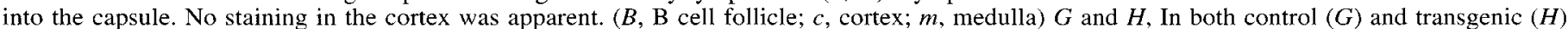

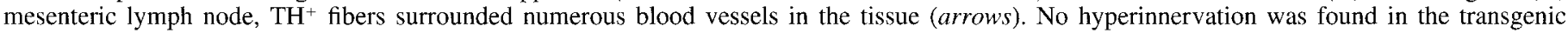
mesenteric lymph node. Scale bars: $A-D$ and $F-H, 100 \mu \mathrm{m} ; E, 500 \mu \mathrm{m}$. 

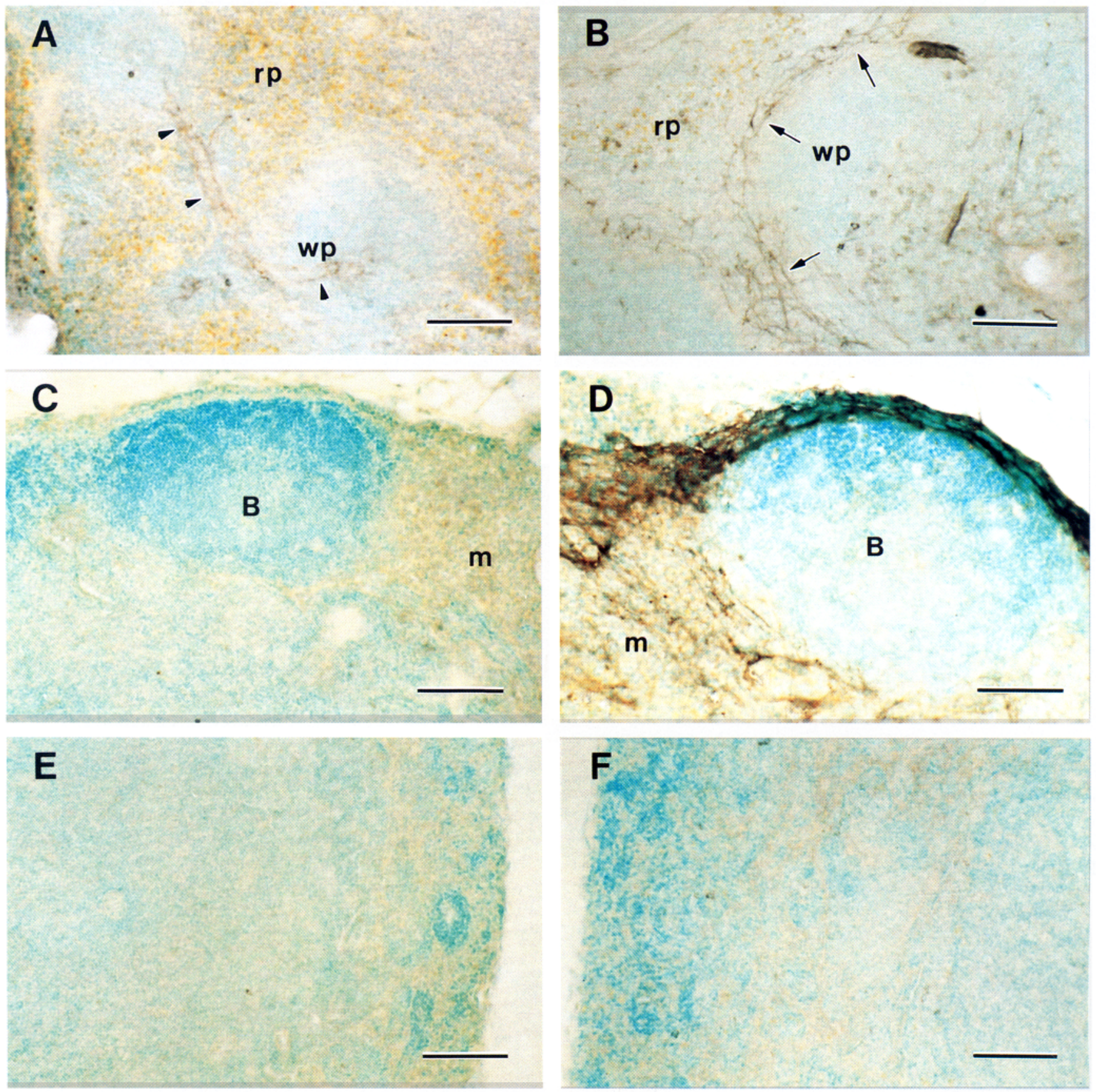

Figure 2. Immunostaining for NGF peptide in control and high expresser transgenic spleen $(A, B)$, axillary lymph node $(C, D)$, and mesenteric lymph node $(E, F) . A$ and $B$, In control spleen $(A)$, faint $\mathrm{NGF}^{+}$staining surrounded the central artery (arrowheads) of the white pulp (wp). No specific staining was apparent in the red pulp $(r p)$. In the transgenic spleen $(B), \mathrm{NGF}^{+}$staining was present around the central artery, and in nerve fibers in the marginal zone (arrows). $C$ and $D$, In control axillary lymph node $(C)$, no specific staining for NGF was present. In transgenic axillary lymph node $(D)$, intense staining for NGF was present in the capsule and medulla. No staining was apparent in the B cell follicles or cortex. $(B$, B cell follicle; $m$, medulla) $E$ and $F$, No specific staining for NGF was apparent in either control $(E)$ or transgenic $(F)$ mesenteric lymph node. Scale bars, $100 \mu \mathrm{m}$.

nodes and spleen samples from control and transgenic mice (Fig. $3 A)$. Reaction efficiency was monitored using actin mRNA amplification. In the first experiments, primers specific for an internal sequence of the NGF coding region were used. These primers would detect endogenous or transgene derived NGF production. The results showed similar low levels of NGF expression in all transgenic and control samples.

To further verify that the K14-NGF transgene was not ex- pressed in lymphoid tissues, RT-PCR analysis was carried out using primers that amplified a region that overlapped the $\mathrm{hGH}$ $3^{\prime}$ and NGF coding sequence regions and thus was specific for the transgene (Fig. 3B). As expected, no product was detected in the lymphoid tissue samples. These primers have consistently shown transgene product in skin samples of the transgenic mice, and selective expression of the transgene in K14-positive tissues has previously been shown (Albers et al., 1994; Davis et al., 


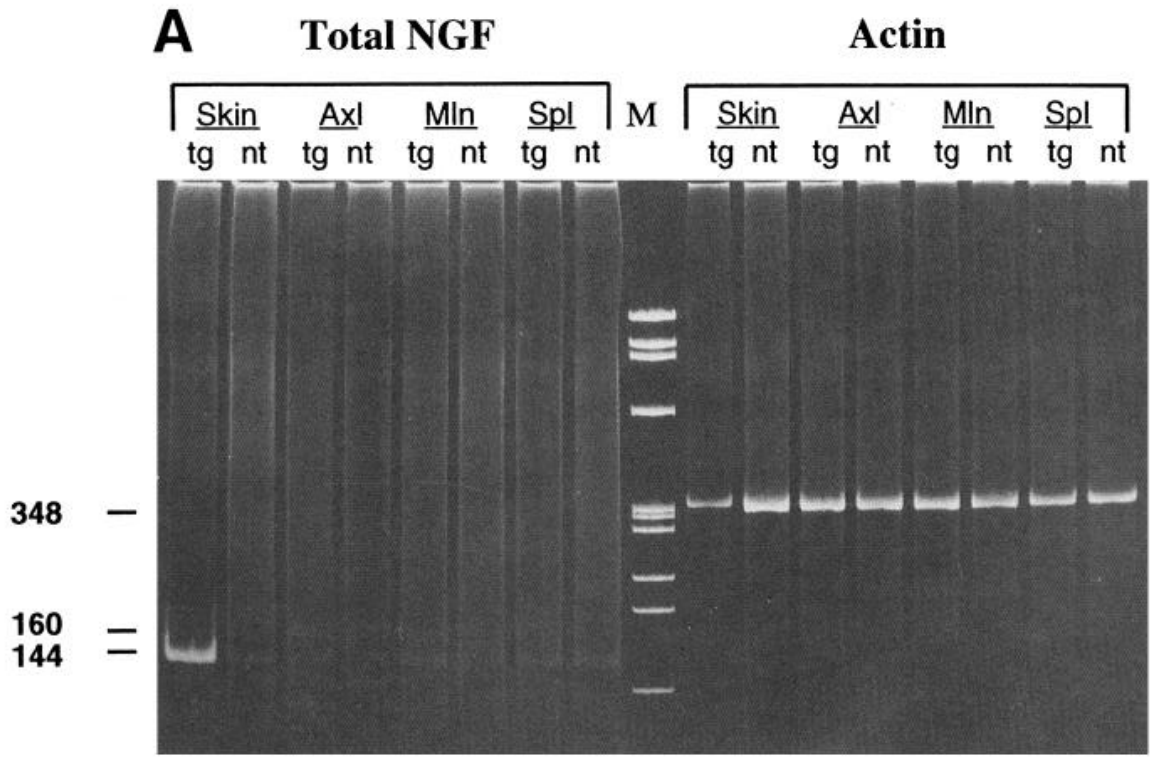

\section{B Transgene}

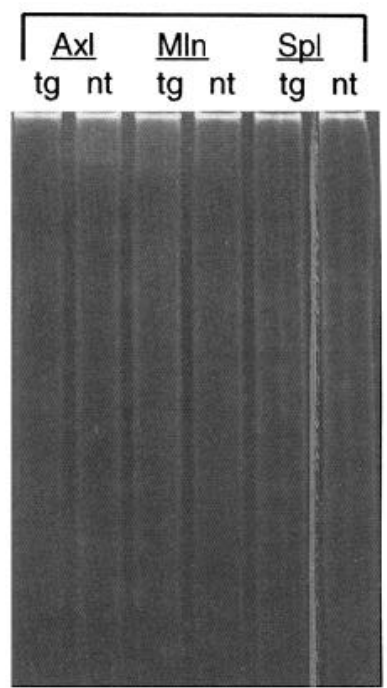

Figure 3. Transgene derived NGF is not synthesized in the transgenic lymphoid tissues. A, Total RNA was isolated from nontransgenic (nt) and transgenic $(t g)$ skin, axillary lymph nodes $(A x l)$, mesenteric lymph nodes $(M l n)$, and spleen $(S p l)$. Samples were DNased and used for reverse transcription assays. One RT reaction was carried out for each sample after which the reaction was split into equal portions and PCR amplified using primers to either NGF or actin. Actin was used as an internal control for reaction efficiency. Products were precipitated and loaded on an $8 \%$ polyacrylamide gel that was EtBr stained. Amplification of actin cDNAs produce a band at 348 bp whereas NGF cDNAs produce a band at 144 bp. Note that NGF levels in all lymphoid tissues are low and not elevated in the transgenic samples. Transgenic skin is included as a positive control for the NGF product. Markers are $\Phi$ X174 HaeIII fragments. $B$, Total RNA was reverse transcribed and PCR amplified using primers specific for the K14-NGF transgene which, if present, produce a fragment of $160 \mathrm{bp}$. No evidence of transgene expression in lymphoid tissues was apparent.

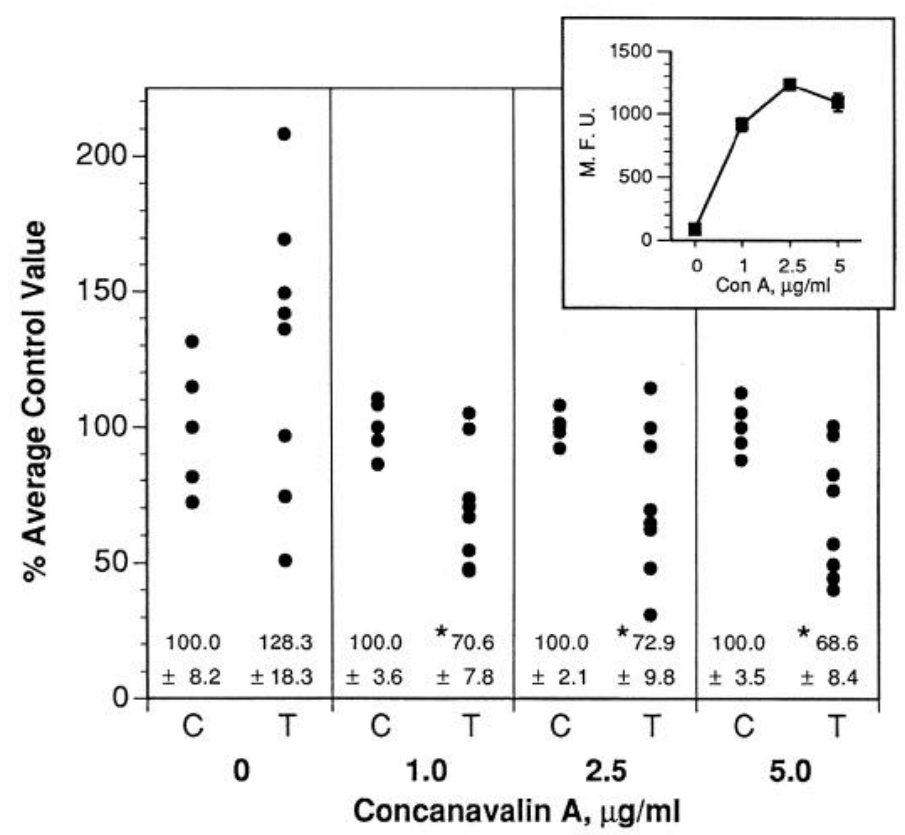

Figure 4. The mitogen response to ConA is decreased in transgenics. Spleen cells were incubated $72 \mathrm{hr}$ with various doses of ConA, and the proliferation detected with Alamar blue and a fluorescence plate reader. Data for each animal ( $n=6$, controls; 8 , transgenics) is expressed as the percent of the average control value for each dose of ConA. Proliferation of the transgenic spleen cells was significantly decreased at each of the ConA dilutions used. The inset shows the average fluorescence of control wells: 0 ConA, $83.93 \pm 10.08 ; 1 \mu \mathrm{g} / \mathrm{ml}, 913.20 \pm 53.47$; $2.5 \mu \mathrm{g} / \mathrm{ml}, 1232.92 \pm 46.81 ; 5 \mu \mathrm{g} / \mathrm{ml}, 1089.75 \pm 69.70$. *,$p<0.05$.
1994). Thus, the low level of NGF mRNA detected with the first set of primers was from the endogenous NGF gene.

Decreased mitogen response to ConA in transgenics. Spleen cells were stimulated with various concentrations of the T-cell mitogen ConA. All concentrations of ConA stimulated proliferation, with the peak response for control and transgenics at $2.5 \mu \mathrm{g} / \mathrm{ml}$ ConA (Fig. 4, inset). The proliferation of transgenic spleen cells was significantly decreased at each of the ConA concentrations (1, 2.5, $5 \mu \mathrm{g} / \mathrm{ml}$; Fig. 4). Most of the transgenics (6 of 8) showed a profound decrease in proliferation (up to $50 \%$ decrease); however, the response of two of the mice was not different from controls at any concentration.

\section{Discussion}

Though innervation of lymphoid tissues by sympathetic postganglionic neurons has been well documented (Felten et al., 1987; Felten and Felten, 1991), much remains unknown about the factors that control the density and pattern of innervation and the significance of this innervation on the immune response. Trophic factors such as NGF, which are essential for the survival of sympathetic neurons (Levi-Montalcini and Angeletti, 1968; Harper and Thoenen, 1980), could play a key role in the development and maintenance of lymphoid innervation. To study this issue, we examined various lymphoid tissues of NGF transgenic mice for sympathetic fiber content and distribution. Our results show that many, though not all, transgenic lymphoid tissues were hyperinnervated and displayed alterations in fiber distribution when compared to control tissues. In spleen, hyperinnervation of the marginal zone of the white pulp was striking and 
correlated with the level of NGF peptide, that is, transgenics expressing high NGF levels (A-56 mice) had a more dense plexus in the marginal zone than found in the medium expressing (A-47) mice. Interestingly, the pattern of fiber distribution in the adult transgenic is similar to that seen in developing rat spleen. In rat, splenic innervation occurs postnatally and appears first in the developing marginal zone prior to establishing the adult pattern which is predominantly around the central artery and in the white pulp parenchyma (Felten et al., 1987; Ackerman et al., 1989). Thus, elevated NGF levels in transgenic mice may stabilize the embryonic pattern of innervation around the marginal zone and alter the development of the mature pattern. Future developmental studies will determine if increased NGF in transgenic mice does in fact "freeze" the innervation to the marginal zone and decrease the progression of innervation to the central artery and white pulp.

In peripheral lymph nodes (i.e., axillary and cervical) of transgenic mice, hyperinnervation was evident in the medulla and capsule, compartments that normally have a low degree of innervation (Felten et al., 1984, 1987). As in spleen, the degree of hyperinnervation correlated with the level of NGF peptide in the tissue as measured by FI ISA and the pattern of NGF by immunocytochemistry. In contrast, the transgenic mesenteric lymph nodes, which had control levels of NGF, were not hyperinnervated in either line of transgenic mice. Thus, the level of sympathetic hyperinnervation was proportional to the level of NGF, a relationship previously described for a variety of tissues (Korsching and Thoenen, 1983; Shelton and Reichardt, 1984).

That NGF guides sympathetic innervation of lymphoid tissues in normal mice is consistent with studies that reveal lymphocytes produce NGF (Ehrhard et al., 1993; Santambrogio et al., 1994). In support of this, spleen, but not mesenteric lymph nodes, can induce neurite outgrowth from superior cervical ganglia in vitro which can be blocked with anti-NGF antibody (Kannan et al., 1994). In addition, lymphocytes and monocytes have been shown to express NGF receptors (Thorpe et al., 1987a; Otten et al., 1989; Kittur et al., 1992; Ehrhard et al., 1993), suggesting that NGF has both immune and neural targets in lymphoid tissues.

Presently it is not clear why only the peripheral lymph nodes, and not the mesenteric lymph nodes, contain elevated NGF levels in the transgenic mice. One possibility is that NGF produced in the overlying skin is released into the blood or lymph, and is concentrated in certain immune tissues as these fluids are filtered. Measurements of NGF in skin by ELISA have shown up to a fourfold increase in transgenics compared to controls (unpublished observation), a value similar to the increase in NGF found in spleen. In contrast the increase in NGF peptide in the axillary lymph nodes, which are exposed to lymph drained from the skin, was much greater (13-fold) suggesting that NGF was being concentrated in these tissues. In contrast, the lack of elevation in NGF in the mesenteric lymph nodes, which drain lymph from the gut, suggests that these nodes do not concentrate NGF or are not exposed to elevated NGF from the blood.

The mechanism by which elevated NGF levels induce hyperinnervation is not clear. One possibility is that this innervation pattern is a nonspecific result of the hypertrophy of the sympathetic ganglia. The sympathetic ganglia, including the superior cervical ganglion (Albers et al., 1994), the sympathetic chain, and collateral ganglia (unpublished observations) are hypertrophied in the transgenics. However, the spleen which is hyperinnervated, and the mesenteric lymph nodes which are not, are likely to receive fibers from the same sympathetic ganglia, that is, superior mesenteric/celiac ganglion and lower thoracic sympathetic chain ganglia (Bellinger et al., 1989; Nance and Burns, 1989). If ganglia are shared, it suggests that tissue specific factors are involved in establishing the innervation pattern and density. It is possible that factors that inhibit as well as promote axonal ingrowth reside within specific lymphoid tissues. These factors also may be important in establishing innervation to specific tissue compartments such as the marginal zone of the spleen and medulla of peripheral lymph nodes.

Another possibility is that NGF acts as a chemotropic agent, a hypothesis that has been intensively investigated and debated (Gunderson and Barrett, 1979; Gunderson and Barrett, 1980; Lumsden and Davies, 1983; Davies et al., 1987; Hoyle et al., 1993; Davis et al., 1994) Also, since sympathetic fibers are normally found in lymphoid tissue, the transgenic pattern of innervation could be due, in part, to sprouting of local sympathetic fibers (Diamond et al., 1992; Isaacson et al., 1992). However, the unique nature of the transgenic sympathetic projection can not be completely explained by sprouting alone.

The results of the mitogen assays demonstrate that the immune system is altered functionally in the transgenic mice. The decrease in proliferation to ConA is not the result of altered ratios of $\mathrm{T}$-cell subsets as the percent of $\mathrm{CD}^{+}$or $\mathrm{CD}^{+}$cells in spleen was not different in the transgenics (unpublished observations). The change in proliferative capacity may be a direct effect of the elevated NGF or of the enhanced tissue innervation. Both NGF (Thorpe and Perez-Polo, 1987; Thorpe et al., 1987b; Otten et al., 1989) and catecholamines (Madden and Livnat, 1991; Roszman and Carlson, 1991) have been shown to alter immune responses, including proliferation.

While the exact mechanism by which NGF affects immune system development and function are just beginning to be identitied, it is clear from the present data that NGF plays a central role in establishing the pattern of catecholamine innervation. Because of the presence of NGF receptors on lymphoid cells and its ability to affect the adult sympathetic nervous system, it is likely that NGF could be a modulator of immune function in the adult as well. Thus these mice will provide an excellent model system to examine the interactions between catecholamines, NGF and the immune system both during critical periods of development and in the adult.

\section{References}

Ackerman KD, Felten SY, Dijkstra CD, Livnat S, Felten DL (1989) Parallel development of noradrenergic innervation and cellular compartmentation in the rat spleen. Exp Neurol 103:239-255.

Ahmed SA, Gogal RM, Walsh JE (1994) A new rapid and simple nonradioactive assay to monitor and determine the proliferation of lymphocytes: an alternative to $\left[{ }^{3} \mathrm{H}\right]$ thymidine incorporation assay. J Immunol Methods 170:211-224.

Albers K, Wright DE, Davis BM (1994) Overexpression of nerve growth factor in epidermis of transgenic mice causes hypertrophy of the peripheral nervous system. J Neurosci 14:1422-1432.

Bellinger DL, Felten SY, Lorton D, Felten DL (1989) Origin of noradrenergic innervation of the spleen in rats. Brain Behav Immun 3:291-311.

Carlson SL, Trauth K, Brooks WH, Roszman TL (1994) Enhancement of $\beta$-adrenergic-induced cAMP accumulation in activated T-cells. J Cell Physiol 161:39-48.

Cheng J, Turksen K, Yu Q-C., Schreiber H, Teng M, Fuchs F, (1992) Cachexia and graft-vs-host-disease-type skin changes in keratin promoter-driven TNFa transgenic mice. Genes Dev 6:1444-1456.

Conner JM, Muir D, Varon S, Hagg T, Manthorpe M (1992) The localization of nerve growth factor-like immunoreactivity in the adult 
rat basal forebrain and hippocampal formation. J Comp Neurol 319: $454-462$.

Creedon DJ, Tuttle JB (1988) Cultured smooth muscle targets lack survival activity for ciliary ganglion neurons. J Neurosci 8:31003110.

Davies AM, Bandtlow C, Heumann R, Korsching S, Rohrer H, Thoenen $H$ (1987) Timing and site of nerve growth factor synthesis in developing skin in relation to innervation and expression of the receptor. Nature 326:353-358.

Davis BM, Katz DM, Seroogy KB, Albers KM (1994) Overexpression of NGF in transgenic mice induces novel sympathetic projections to primary sensory neurons. J Comp Neurol 349:464-474.

Diamond J, Holmes M, Coughlin M (1992) Endogenous NGF and nerve impulses regulate the collateral sprouting of sensory axons in the skin of the adult rat. J Neurosci 12:1454-1466.

Edwards RH, Rutter WJ, Hanahan D (1989) Directed expression of NGF to pancreatic B cells in transgenic mice leads to selective hyperinnervation of the islets. Cell 58:161-170.

Ehrhard PB, Erb P, Graumann U, Otten U (1993) Expression of nerve growth factor and nerve growth factor receptor tyrosine kinase Trk in activated CD4-positive T-cell clones. Proc Natl Acad Sci USA 90: 10984-10988.

Felten SY, Felten DL (1991) Innervation of lymphoid tissue. In: Psychoneuroimmunology, 2d ed (Ader R, Felten DL, Cohen N, eds), pp 27-61. San Diego: Academic.

Felten SY, Olschowka J (1987) Noradrenergic sympathetic innervation of the spleen. II. Tyrosine hydroxylase (TH)-positive nerve terminals form synapticlike contacts on lymphocytes in the splenic white pulp. J Neurosci Res 18:37-48.

Felten DL, Livnat S, Felten SY, Carlson SL, Bellinger DL, Yeh P (1984) Sympathetic innervation of lymph nodes in mice. Brain Res Bull 13:693-699.

Felten DL, Felten SY, Bellinger DL, Carlson SL, Ackerman KD, Madden KS, Olschowka JA, Livnat S (1987) Noradrenergic sympathetic neural interactions with the immune system: structure and function Immunol Rev 100:225-260.

Gunderson RW, Barrett JN (1979) Neuronal chemotaxis; chick dorsalroot axons turn toward high concentrations of nerve growth factor. Science 206:1079-1080.

Gunderson RW, Barrett JN (1980) Characterization of the turning response of dorsal root neurites toward nerve growth factor. J Cell Biol 87:546-554.

Harper GP, Thoenen H (1980) Nerve growth factor: biological significance, measurement, and distribution. J Neurochem 34:5-16.

Hoyle GW, Mercer EH, Palmiter RD, Brinster RL (1993) Expression of NGF in sympathetic ncurons leads to excessive axon outgrowth from ganglia but decreased terminal innervatoin within tissues. Neuron 10:1019-1034.

Isaacson LG, Saffran BN, Crutcher KA (1992) Nerve growth factorinduced sprouting of mature, uninjured sympathetic axons. J Comp Neurol 326:327-336.

Kannan Y, Stead RH, Goldsmith CH, Bienenstock J (1994) Lymphoid tissues induce NGF-dependent and NGF-independent neurite outgrowth from rat superior cervical ganglia explants in culture. J Neurosci Res 37:374-383.

Kittur SD, Song L, Endo H, Adler WH (1992) Nerve growth factor receptor gene expression in human peripheral blood lymphocytes in aging. J Neurosci Res 32:444-448.

Korsching S, Thoenen H (1983) Nerve growth factor in sympathetic ganglia and corresponding target organs of the rat: correlation with the density of sympathetic innervation. Proc Natl Acad Sci USA 80: 3513-3516.

Krawietz W, Werdan K, Schober M, Erdmann E, Rindfleisch GE, Hannig K (1982) Different numbers of $\beta$-receptors in human lymphocyte subpopulations. Biochem Pharmacol 31:133-136.

Levi-Montalcini R, Angeletti PU (1968) Nerve growth factor. Physiol Rev 48:534-569.

Lumsden AGS, Davies AM (1983) Earliest sensory nerve fibres are guided to peripheral targets by attractants other than nerve growth factor. Naturc 306:786-788.

Madden KS, Livnat S (1991) Catecholamine action and immunologic reactivity. In: Psychoneuroimmunology, $2 \mathrm{~d}$ ed (Ader R, Felten DL, Cohen N, eds), pp 283-310. San Diego: Academic.

Nance DM, Burns J (1989) Innervation of the spleen in the rat: evidence for absence of afferent innervation. Brain Behav Immun $3: 281-290$.

Otten U, Ehrhard P, Peck R (1989) Nerve growth factor induces growth and differentiation of human B lymphocytes. Proc Natl Acad Sci USA 86:10059-10063.

Pochet R, Dellespesse G, Gausset PW, Collet H (1979) Distribution of beta-adrenergic receptors on human lymphocyte subpopulations. Clin Exp Immunol 38:578-584.

Roszman TL, Carlson SL (1991) Neurotransmitters and molecular signalling in the immune response. In: Psychoneuroimmunology, $2 \mathrm{~d}$ edition (Ader R, Felten DL, Cohen N, eds), pp 311-339. San Diego: Academic.

Santambrogio L, Benedetti M, Chao MV, Muzaffar R, Kulig K, Gabellini N, Hochwald G (1994) Nerve growth factor production by lymphocytes. J Immunol 153:4488-4495.

Shelton DL, Reichardt LF (1984) Expression of the $\beta$-nerve growth factor gene correlates with the density of sympathetic innervation in effector organs. Proc Natl Acad Sci USA 81:7951-7955.

Thorpe LW, Perez-Polo JR (1987) The influence of nerve growth factor on the in vitro proliferative response of rat spleen lymphocytes. J Neurosci Res 18:134-139.

Thorpe LW, Stach RW, Hashim GA, Marchetti D, Perez-Polo JR (1987a) Receptors for nerve growth factor on rat spleen mononuclear cells. J Neurosci Res 17:128-134.

Thorpe LW, Werrbach-Perez K, Perez-Polo JR (1987b) Effects of nerve growth factor on the expression of interleukin-2 receptors on cultured human lymphocytes. Ann NY Acad Sci 496:310-311.

Watson RE, Wiegand SJ, Clough RW, Hoffman GE (1986) Use of cryoprotectant to maintain long-term peptide immunoreactivity and tissue morphology. Peptides 7:155-159. 